\title{
Effect of Compensation, Communication and Spirituality at Work on the Performance of the Turnover Intention as an Intervening Variable
}

\author{
Sumiati \\ Lecture Economics and Business Faculty, \\ University of 17 Agustus 1945 Surabaya, Indonesia \\ Nur Hasan \\ Study at PT. Shamsindo Indonusa Suara Musilm Radio Network \\ Surabaya, Indonesia
}

\begin{abstract}
The purpose of this study are (1) To determine and analyze the effect of compensation towards employee turnover intention. (2) To determine and analyze the influence of compensation on employee performance. (3) To determine and analyze the effect of communication on the employee turnover intention. (4) To determine and analyze the effect of communication on employee performance. (5) To determine and analyze the influence of spirituality in the workplace on employee turnover intention. (6) To determine and analyze the influence of spirituality in the workplace on employee performance. (7) To determine and analyze the effect on the performance of the employee turnover intention. The research approach used in this study is a quantitative research. This type of research is explanatory research using a survey method. The sample used in this study saturated or census sampling means that the number of samples as similar as to the number of population are 84. To further analyzed using the methods and analysis techniques Partial Least Square (PLS). The results showed that compensation, communication, and spirituality of the performance of employees have positive and significant influence, compensation and spirituality in the workplace against turnover intention have a negative impact significantly, the communication on turnover intention have a negative impact not significant and turnover intention of the performance have a negative impact not significant.
\end{abstract}

Keywords: Compensation, Communication, Spirituality in the workplace, Turnover intention, Employee performance

\section{INTRODUCTION}

Within the last 5 years the rate of turnover Muslim Voices Radio Network employees is high enough it can be seen from the high percentage of employees who left the company. Percentage of turnover in 2012 amounted to 19\%, in 2013 by $24 \%$, in 2014 by 32\%, in 2015 by $16 \%$ and in 2016 by 24\%. The average turnover Muslim Voices Radio Network reaches 23\% per year, it falls within the category of high. Among the factors the high rate of employee turnover Muslim Voices Radio Network is not still standard due compensation received by employees, especially those in the lower level.

The early symptoms of the turnover is usually characterized by their desire to move the socalled turnover intentions (Intention exit). According Zeffane turnover intention is the tendency or intention of employees to stop work on the job [14]. Employee turnover intention will have an impact on the performance of employees who are not productive and are likely to do undisciplined which would be detrimental to the company [7]. This is consistent with Alfatania Pandu Asmara's research with the title "The Influence of Employee Turnover Intention to 
Performance Surgical Hospital in Surabaya"[3]. The results showed turnover intention affect the performance of the employee with p value or significant of 0.03 and smaller than $\alpha=5 \%$ (0.05). It can be concluded that the turnover intention affects the performance of employees.

However, the above theory does not apply in Muslim Voices Radio Network, a high turnover intention not affect the performance of Muslim Voices Radio Network employee. This is evident in a period of 7 years according to research conducted by Nielsen Company (2017) SMRN be the most listeners of radio media in third place in the region of the range of Gresik area, Bangkalan, Mojokerto, Surabaya, Sidoarjo and Pasuruan.

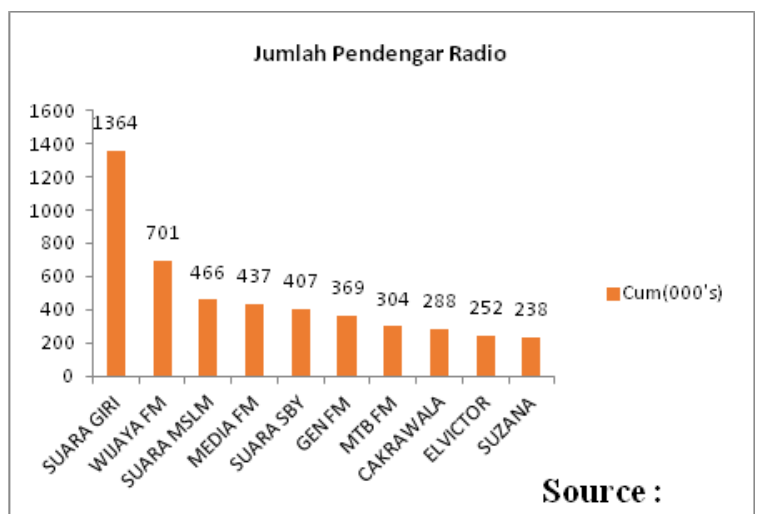

Figure a. The number of listeners Muslim Vote 2017

Alleged while researchers there are factors that cause the turnover intention no significant effect on the performance of employee in Muslim Voices Radio Network. These factors include the highly-developed communication in the work environment Muslim Voices Radio Network so as to affect the performance of the employee's reached mutual success.

Another thing that causes turnover intention not affect the performance, according to researcher's conjecture is the strong factor of spirituality in the workplace. Muslim voice of Radio Network is the radio medium that gives great attention to spirituality that is reflected in the organization's culture SMRN "1 - 2 - 5": 1 Basic, 2 Pillar, 5 Attitude. The basic aspects are the dawn Love is commitment from all employees to morning prayers at the mosque in congregation for men and at home beginning of time for female employees. Aspect 2 is the pillar of Professional and Teamwork, and its implementation is a five attitude aspects namely trust, best charity, discipline, familial and encourage one another. The application of spiritual values is expected to grow high performance employees, so that the company makes the application of the values above as part of employee performance benchmarks. This aspect is very dominant researchers expected to grow at a Muslim Voices Radio Network employees so that employee productivity is maintained.

\section{Compensation}

\section{LITERATURE REVIEW}

Compensation is something that is received by the employee as a reward for his achievements in implementing the tasks [10]. Every company should be fair in giving compensation in accordance with the employee's work load. According Sitohang, the compensation is setting the overall provision of remuneration for employees and managers, both financially and in the form of goods and services received by each employee [12]. Drs. Malay SP Hasibuan the compensation is all the income in the form of money, goods directly or indirectly received by employees as a reward for services rendered to the company [8]. The indicators compensated by Noe in Aulia and Troena [4] includes: 


\section{- Wages / salaries \\ - Incentive \\ - Allowances.}

\section{Communication}

Etymologically, the term comes from the Latin communication and speech communication originates in the word communis. The meaning here is the same in the sense of equal significance is the same meaning about something. The similarity of meaning in the process of communication is an important factor due to the similarity of meaning between communicants and communicators that communication can take place and better understanding.

In the terminology, communication means the process of delivering a statement by one person to another. Communication can be done directly or using the media. Examples of direct communication without the media are planning face conversation, face-to-face speech and others, while an example of communication using media is talking on the phone, listening to the news on the radio or television and others. According to Effendy the communication is done with the aim to attitude change, opinion change, behavior change and social change [5].

\section{Spirituality in the Workplace}

Spirituality in the workplace is often also called Islamic work environment which is everything that is Islamic who were around employees who can influence and support a person in carrying out the activities. In Ashmos and Duchon (2000) state that in order to understand the notion of spirituality in the workplace must begin with the recognition that each person has a personal life (inner) and life outcomes (outer) and that the development of personal life can lead to the outdoor life more meaningful and more productive [2]. Recognition of spirituality in the workplace means looking at the workplace as a place inhabited by people who have the mind (intellect) and the spirit, and believe that the development of the spirit is as important as developing the mind.

Environment in the workplace have a considerable influence on the smooth operation of the company, so that ultimately can affect the productivity of the company in general, therefore, the management companies that make up the work environment should consider the convenience of employees, since most employees want a room conditions and safe working comfortable so be very pleasant working atmosphere.

\section{Turnover Intention}

Based on the theory of reasoned action proposed by Fishbein and Ajzen can be seen that the behavior of turnover can be measured by intention of the behavior of turnover (turnover intention). Mobley et al. concluded that turnover intention is an early sign of turnover behavior, because there is a significant relationship between turnover intention and turnover behavior that occurs [11].

Turnover intention is the tendency or intention of employees to stop work on the job [11]. Turnover intention refers to the individual evaluation results of the continuation of individual relationship with the organization and has not been realized in the action would have left the organization [9]. Turnover intention is also defined as a mediating factor between attitudes affect the intention to stop and actually stop of an organization [6]. 
The factors that influence the occurrence of turnover is quite complex and intertwined with each other. among those factors that will be discussed include age, length of employment, education, commitment to the organization, job satisfaction and corporate culture.

\section{Performance}

Performance comes from Job Performance or Actual Performance (actual job performance or achievements attained by someone) [1]. Performance is the performance or results of HR work achieved both in quality and quantity of the unity of the time period in performing its work in accordance with the responsibilities given to him [1].

Performance is the performance or results of HR work achieved both in quality and quantity of the unity of the time period in performing its work in accordance with the responsibilities given to him [1]. Performance also means one achieves results both quality and quantity in accordance responsibilities given to him. In addition, the performance of a person affected by level of education, initiative, work experience and the spiritual leadership of employees. The work of someone will give feedback on one's own to always actively works well and is expected to produce a good quality of work.

Understanding performance by Hasibuan is the result of the quality and quantity of work accomplished by an employee in performing their duties in accordance with the responsibilities given to him. Performance or work performance is a result of work achieved by a person in performing assigned tasks [8]. Similar definition was also expressed by Rival states that the performance is a result or level of a person's success as a whole over a certain period in the duty compared to the wide range of possibilities, such as the standard of the work, the target or targets or criteria that have been determined in advance and have been agreed [8].

\section{Conceptual Framework}

Conseptual framework is a systematic overview of the relationship which shall be examined variables that influence compensation, communication and spirituality in the workplace on turnover intention and its impact on employee performance Muslim Voices Radio Network as follows:

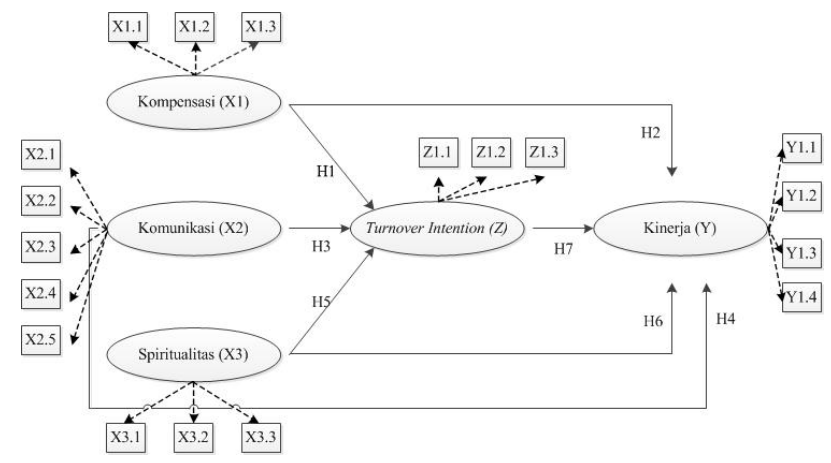

Figure b. Conceptual Framework

\section{RESEARCH HYPOTHESIS}

The hypothesis of the proposed research is (1) Compensation effect on turnover intention of employees Voice Muslim Radio Network, (2) compensation effect on employee performance Voice Muslim Radio Network, (3) communication effect on turnover intention of employees Voice Muslim Radio Network, (4) communication effect on employee performance Voice Muslim Radio Network, (5) spirituality in the workplace affect the turnover intention of employees Voice Muslim Radio Network, (6) the spirituality in the workplace affects the 
employee's performance Voice Muslim Radio Network, (7) turnover intention affect the performance employees Muslim Voices Radio Network.

\section{RESEARCH METHODS}

The research approach used in this study is a quantitative research. This type of research used in this research is the explanation (explanatory reesearch) using survey methods, the research seeks to explain the influence of the independent variables on the dependent variable.

The target population in this study are those who work as crew program, technicians, Account Executive, marketing and administrative staff numbering 84 people. Because the population is not too much so in this study used a sample of saturated or census means that the number of samples is equal to the number of population is 84 employees Muslim Voices Radio Network. According Sugiyono the sample is saturated or census sampling technique when all members of the population used as a sample [13].

To facilitate the planning of the data, the research variables can be divided into the independent variable $(\mathrm{X})$ and the dependent variable $(\mathrm{Y})$. The independent variable $(\mathrm{X})$ in this study consists of:

Variable compensation (X1) with the indicator (a) wage or salary, (b) incentives, (c) allowances.

1. Communication variables (X2) with indicator (a) wise and decency, (b) the receipt of feedback, (c) information sharing, (d) provide information tasks, (e) reduce the uncertainty of the task.

2. Spirituality in the workplace variable (X3) with indicator (b) enforcement of values, (b) a sense of meaning in work, (c) feeling of being connected with the community.

3. Variable turnover intention (Z) with indicator (a) mind to come out, (b) the desire to look for another job opening, (c) a desire to leave the organization in the coming months.

4. The dependent variable (Y) with indicator (a) quality, (b) the quantity, (c) the execution of tasks, (c) responsibility.

Data analysis techniques performed with descriptions analysis, correlation, regression, determination, Test-F and t-test were used to determine significant effect partially independent variables on the dependent variable.

\section{RESULTS AND DISCUSSION}

The results of this research includes several variables of Compensation, Communication, Spirituality in the workplace, Employee turnover intention and Performance and after analysis obtained the following results:

Table 1. Description Average Answer Respondents About The variables studied

\begin{tabular}{|l|c|l|}
\hline \multicolumn{1}{|c|}{ Variables } & Average & Category \\
\hline Compensation & 3.01 & Enough \\
\hline Communication & 3.83 & High \\
\hline Spirituality in the workplace & 3.86 & High \\
\hline Turnover intention & 2.37 & Low \\
\hline Performance & 4.03 & High \\
\cline { 2 - 3 } &
\end{tabular}

Source: Data processed

From table 1 it can be seen that the variable compensation is measured by several indicators, namely wage or salary, incentives, benefits get it demonstrates the value of 3.01 of 
compensation according to the perception of respondents included in the category enough. Dimension wise communication with the indicator and courtesy, receiving feedback, share information, provide information about the task, the task of reducing uncertainty had an average score of respondents is 3.83. This indicates that the level of communication that occurs included in both categories. Dimensions of spirituality in the workplace with enforcement indicator values, sense of meaningful work and feeling of being connected with the community, the perception of respondents with an average score of 3.86, which means employees feel the spirituality in the workplace included either. Dimensions turnover intention with indicators of mind to go out, the desire to look for another job, the desire to leave the organization next few months had an average score of 2.37 is included in the low category, it indicates the employee wants to keep contributing in Muslim Voices Radio Network. While the average performance of 4.03 respondents included in the high category, which means that the performance of employees Muslim Voices Radio Network including well.

Subsequent analysis begins with the validity and reliability of the questionnaire using data presampling number of 30 respondents. The results of the validity of the statement items have a valid study of each variable with a value Person Product Moment generate significant value less than $5 \%$. While the reliability test results are generating Cronbach's Alpha value $>0.60$ so that each variable has a valid research.

SEM data processing method begins by assessing Outer Model or Measurement Model. There are three criteria in the use of data analysis techniques to assess the outer SmartPLS models: Convergent Validity, Composite Discriminant Validity and Reliability. Convergent Validity of the measurement model with a reflexive use limit indicator loading factor of 0.5. Loading Factor for the first latent variable is the variable compensation are:

Table 2. Loading Factor Compensation

\begin{tabular}{|c|c|c|c|}
\hline & $\mathrm{X} 11$ & $\mathrm{X} 12$ & $\mathrm{X} 13$ \\
\hline $\mathrm{X} 1.1 .1$ & .930 & & \\
\hline $\mathrm{X} 1.1 .2$ & ${ }^{*} \mathbf{0 . 3 9 1}$ & & \\
\hline $\mathrm{X} 1.1 .3$ & $\mathbf{0 . 8 8 6}$ & & \\
\hline $\mathrm{X} 1.2 .1$ & & $\mathbf{0 , 8 8 0}$ & \\
\hline $\mathrm{X} 1.2 .2$ & & .881 & \\
\hline X1.2.3 & & .873 & \\
\hline X1.3.1 & & & .832 \\
\hline X1.3.2 & & & $\mathbf{0 . 8 9 1}$ \\
\hline X1.3.3 & & & .846 \\
\hline
\end{tabular}

Table 2 shows the testing of value loading factor of the first order. The highest value of testing is X1.1.1 loading factor of 0.930 and the lowest value of the test loading factor is X1.1.2 is 0.391. Because the value is less than 0.5, then the indicator should be eliminated. So that the resulting modification factor loading value in the table below: 


Table 3. Loading Factor Compensation (Modifica
\begin{tabular}{|l|c|c|c|}
\hline & X11 & X12 & X13 \\
\hline X1.1.1 & 0.946 & & \\
\hline X1.1.3 & 0.922 & & \\
\hline X1.2.1 & & 0,880 & \\
\hline X1.2.2 & & .881 & \\
\hline X1.2.3 & & .873 & \\
\hline X1.3.1 & & & .832 \\
\hline X1.3.2 & & & 0.891 \\
\hline X1.3.3 & & & .845 \\
\hline
\end{tabular}

Based on Table 3 above shows a modified form of the test loading factor value of the first latent construct in first. X1.1.2 indicator removed after the results of the tests no modification loading factor of less than less than 0.5 so that all indicators are already considered to be adequate.

5:19 The next table will explain the value loading factor The second latent variables namely Communication as follows:

Table 4. Loading Factor Communication

\begin{tabular}{|l|c|c|c|c|c|}
\hline & X21 & X22 & X23 & X24 & X25 \\
\hline X2.1.1 & 0.865 & & & & \\
\hline X2.1.2 & 0.804 & & & & \\
\hline X2.1.3 & 0.819 & & & & \\
\hline X2.2.1 & & 0.901 & & & \\
\hline X2.2.2 & & 0.835 & & & \\
\hline X2.2.3 & & 0.904 & & & \\
\hline X2.3.1 & & & 0.796 & & \\
\hline X2.3.2 & & & .820 & & \\
\hline X2.3.3 & & & .852 & & \\
\hline X2.4.1 & & & & 0.875 & \\
\hline X2.4.2 & & & & 0,806 & \\
\hline X2.4.3 & & & & 0.841 & \\
\hline X2.5.1 & & & & & .950 \\
\hline X2.5.2 & & & & & .938 \\
\hline X2.5.3 & & & & & 0.911 \\
\hline
\end{tabular}

Source: Appendix Loading Factor

Based on Table 4 above shows the testing of value loading factor of the first order latent construct in second. The value of the loading factor testing no less than less than 0.5 , then there is no indicator that should be eliminated. The highest factor loading value is 0.950 at X2.5.1 while lowest loading factor value is 0.796 in X2.3.1.

Next grades loading factor of three latent variables that spirituality will be explained in 5:20 the following table: 
Table 5. Loading Factor spirituality

\begin{tabular}{|l|c|c|c|}
\hline & X31 & X32 & X33 \\
\hline X3.1.1 & .857 & & \\
\hline X3.1.2 & $\mathbf{0 . 8 0 1}$ & & \\
\hline X3.1.3 & $\mathbf{0 , 8 1 6}$ & & \\
\hline X3.2.1 & & $\mathbf{0 . 9 0 8}$ & \\
\hline X3.2.2 & & $\mathbf{0 . 8 9 9}$ & \\
\hline X3.2.3 & & $\mathbf{0 , 9 0 0}$ & \\
\hline X3.3.1 & & & $\mathbf{0 . 9 0 7}$ \\
\hline X3.3.2 & & & .892 \\
\hline X3.3.3 & & & $\mathbf{0 , 8 8 0}$ \\
\hline
\end{tabular}

Source: Appendix Loading Factor

Based on Table 5 above shows the testing of value loading factor of the first order construct in third latent variable Spirituality nothing less than 0.5 , then there is no indicator that should be eliminated. Rated loading factor of 0.907 at X3.3.1 highest and lowest values in X3.1.2 loading factor of 0.801 .

After the first order then the next measurement is to measure the construct according to the second order in a manner involving an average of valid indicators in each dimension of the construct. Results of testing the loading factor of the second stage of the order can be seen in Table 5:21 below:

Table 6. Loading Factor Second Order

\begin{tabular}{|c|c|c|c|c|c|}
\hline & performance & Compensation & Communication & spirituality & TurnoverIntention \\
\hline X1.1 & & .818 & & & \\
\hline X1.2 & & $\mathbf{0 , 8 1 2}$ & & & \\
\hline X1.3 & 0.876 & & & \\
\hline X2.1 & & & & & \\
\hline X2.2 & & & 0.863 & & \\
\hline X2.3 & & 0,848 & & \\
\hline X2.4 & & 0.901 & & \\
\hline X2.5 & & 0.909 & & \\
\hline X3.1 & & & .914 & \\
\hline X3.2 & & & & .942 & \\
\hline X3.3 & & & & & \\
\hline Y1 & $\mathbf{0 , 8 7 7}$ & & & & \\
\hline Y2 & $\mathbf{0 . 8 7 2}$ & & & & \\
\hline Y3 & $\mathbf{0 . 9 0 4}$ & & & & \\
\hline Y4 & .773 & & & & \\
\hline Z1 & & & & & \\
\hline Z2 & & & & & \\
\hline Z3 & & & & & \\
\hline
\end{tabular}

Source: Appendix Loading Factor

From Table 6 above it can be stated that all indicators have a value above 0.5 . The highest value at Z1 of 0.948 while the lowest value in the Y4 at 0.773 .

Then the validity and reliability criteria can also be seen from the reliability of a construct and value Average Variance Extracted (AVE) of each construct. 
The construct is said to have a high reliability if the value is above 0.70 and 0.50 AVE. In Table 7 will be presented Composite Reliability and AVE values for all variables.

Table 7. composite Reliability and Average Variance Extracted (AVE)

\begin{tabular}{|l|c|c|}
\hline & composite Reliability & Average Variance Extracted (AVE) \\
\hline performance & 0.918 & .736 \\
\hline Compensation & 0.874 & 0.698 \\
\hline Communication & 0.943 & 0.767 \\
\hline spirituality & .950 & .864 \\
\hline turnover Intention & 0,959 & 0.887 \\
\hline
\end{tabular}

Information: Valid if Reliability $>0.70$ and $R D>0.50$

Table 7 can be explained based composite reliability indicator value is 0.874 and Compensation AVE value of 0.698. Then indicator Communication has composite reliability and AVE values of 0.943 and 0.767 . Indicators composite reliability spiritual values 0.950 and 0.864 AVE. Further indicators Turnover Intention composite reliability values of 0.959 and $0.887 \mathrm{AVE}$ value. The last indicator that performance composite reliability values of 0.918 and 0.736 AVE value.

Formed structural models were tested to see the relationship between the constructs to see the R-square value of the research model. Table 8 is an R-square estimation using SmartPLS.

Table 8. Table R-Square

\begin{tabular}{|l|r|}
\hline & R-Square \\
\hline performance & 0.72 \\
\hline TurnoverIntention & 0.80 \\
\hline
\end{tabular}

From Table 8 is known that the performance variable R2 of 0.72 which indicates variations latent variables that performance can be explained by the latent variables / constructs the exogenous form of variable compensation, Communication and Spirituality 0.72 while the remaining $28 \%$ can be explained by other variables which has not been explained by the model. Turnover Intention latent variable has a value R2 of 0.80 so that the latent variable Turnover Intention variation can be explained by the variable compensation, Communication and Spirituality at 0.80 while the remaining $20 \%$ is explained by other variables that have not been explained by the model. Percentage of value R2 of smaller latent variable performance when compared to the latent variable Turnover Intention.

To prove the hypothesis of the study to look at the significance of the influence between variables by looking at the parameters and values coefficient $t$ statistical significance. At PLS 3.0 it is done by looking at the Algorithm Boostrapping Report. Boostrapping Results are summarized in Table 9 below: 
Table 9. Path Coefficients (mean, STDEV, T-Values)

\begin{tabular}{|c|c|c|c|c|c|c|}
\hline & $\begin{array}{c}\text { Original } \\
\text { Sample (0) }\end{array}$ & $\begin{array}{c}\text { Sample } \\
\text { Mean (M) }\end{array}$ & $\begin{array}{c}\text { Standard } \\
\text { Deviation } \\
\text { (STDEV) }\end{array}$ & $\begin{array}{c}\text { T Statistics (I } \\
\text { O / STDEV I) }\end{array}$ & P Values & Information \\
\hline $\begin{array}{c}\text { Compensation -> } \\
\text { Performance }\end{array}$ & 0,303 & 0.304 & .150 & 2,019 & 0,044 & Significant \\
\hline $\begin{array}{c}\text { Compensation -> } \\
\text { TurnoverIntention }\end{array}$ & -0.165 & -0.189 & 0.122 & 2,001 & 0.038 & Significant \\
\hline $\begin{array}{c}\text { Communications -> } \\
\text { Performance }\end{array}$ & 0,249 & 0,260 & 0.161 & 2.301 & 0,023 & Significant \\
\hline $\begin{array}{c}\text { Communications -> } \\
\text { TurnoverIntention }\end{array}$ & -0.058 & 0.043 & 0.148 & .393 & 0.694 & Not significant \\
\hline $\begin{array}{c}\text { Spirituality -> } \\
\text { Performance }\end{array}$ & .329 & .350 & .207 & 2,587 & 0,013 & Significant \\
\hline $\begin{array}{c}\text { Spirituality -> } \\
\text { TurnoverIntention }\end{array}$ & -0.460 & -0.439 & 0,156 & 2.956 & 0,003 & Significant \\
\hline $\begin{array}{c}\text { TurnoverIntention -> } \\
\text { Performance }\end{array}$ & -0.029 & -0.013 & 0,146 & .200 & .842 & Not significant \\
\hline
\end{tabular}

Source: Appendix

In Table 9 above demonstrated the direct influence of the independent variables to the dependent variables in the model or can be interpreted as a step to show the level of direct influence on the relationship between variables in the study as follows:

\section{H1: Compensation (X1) directly influence the Turnover Intention (Z)}

Compensation has a negative relationship with Turnover Intention with the original sample values -0.165 and no significant effect on the behavior of Turnover Intention compensation with T-statistic values of 2.001> 1.98. Value and has a P value of 0.038 which is less than 0.05 based on the data PLS 3.0 provides an answer hypothesis 1 (H1) is accepted.

\section{H2: Compensation (X1) directly affects the performance (Y)}

Compensation has a positive relationship with the performance of the original value of 0,303 samples and no significant effect on the performance of compensation with T-statistic values of 2.0101> 1.98. And has a value of P Value 0.044 smaller than 0.05 based on the data PLS 3.0 provides an answer hypothesis 2 (H2) is accepted.

\section{H3: Communications (X2) significantly affects Turnover Intention (Z)}

Communications has a negative relationship with Turnover Intention with the original sample values -0.058 and show kemunikasi no significant effect on Turnover Intention with T-statistic values of $0.393<1.98$. And has a value of $P$ Value 0.694 greater than 0.05 , based on the data PLS 3.0 provides an answer hypothesis 3 (H3) was rejected.

\section{H4: Communication (X2) significantly affects the performance (Y)}

Communication has a positive relationship with performance with the original value and the 0,249 samples showed a significant effect on the performance of communication with Tstatistic values of 2.301> 1.98. Value and has a $P$ value of 0.023 which is less than 0.05 based on the data PLS 3.0 provides an answer hypothesis 4 (H4) is received.

\section{H5: Spirituality (X3) significantly affects Turnover Intention (Z)}

Spirituality has a negative relationship with Turnover Intention with the original value of 0.460 sample and showed a significant effect of spirituality on Turnover Intention with Tstatistic values of 2.956> 1.98. And has a value of P Value 0.003 smaller than 0.05 based on the data PLS 3.0 provide answers Hypothesis 5 (H5) is accepted.

\section{H6: Spirituality (X3) significantly affects the performance (Y)}


Spirituality has a positive correlation with the performance of the original value of 0.329 samples and showed a significant effect of spirituality on the performance of the T-statistic values of 2.587> 1.98. And has a value of P Value 0.013 smaller than 0.05 based on the data PLS 3.0 provide answers Hypothesis 5 (H5) is accepted.

\section{H7: Turnover Intention (Z) significantly affects the performance (Y)}

turnover Intention has a negative correlation with the performance of original sample values 0.029 and shown no effect on the Performance Turnover Intention with T-statistic values of $0.200<1.98$. And has a value of P Value 0.842 greater than 0.05 based on the data PLS 3.0 provides an answer hypothesis 6 (H6) was rejected.

\section{CONCLUSION}

The observation of the respondents on the policy applied Muslim Voices Radio Network in the area of compensation, communication and spirituality in the workplace in pretty good employee value only on the variable compensation is insufficient. It is expected to be the attention of the management to further improve policies towards the improvement of compensation that increases employee performance and turnover rate can be decreased. While testing the hypothesis formulated from getting compensation, communication, and spirituality of the performance of employees have a positive and significant influence, compensation and spirituality in the workplace against turnover intention have a significant negative effect, communication of the turnover intention have no significant negative effect on the performance and turnover intention have a significant negative effect.

\section{References}

A.A. Anwar Prabu Mangkunegara. Manajemen Sumber Daya Manusia, 2002. Perusahaan. Bandung: PT. Remaja Rosdakarya.

Ashmos, D.P. and Duchon, D. "Spirituality at work: a conceptualization and measure”, 2000. Journal of Management Inquiry, Vol. 9 No. 2, pp. 134-45.

Asmara, Pandu Alfatania. Pengaruh Turnover Intention terhadap Kinerja Karyawan di Rumah Sakit Bedah Surabaya, 2017. Jurnal Akuntansi dan Keuangan Indonesia Volume 5, Nomor 2, 2017.

Aulia. Alif Furqoni dan Eka Afnan Troena. Pengaruh Kompensasi Finansial dan Non Finansial Terhadap Motivasi Kerja Karyawan Universitas Brawijaya Hotel Kota Malang, 2013. Malang.

Effendy, Onong Uchjana. Ilmu Komunikasi, Teori dan Praktek, 2006. Bandung: Remaja Rosdakarya.

Glissmeyer, M., Bishop J. W., dan Fass, R. D. Role conflict, role ambiguity and intention to quit the organization: The case of law enforcement, 2008. Academy of Management Journal, 40 (1), 82-111.

Harnoto. Manajemen Sumber Daya Manusia, 2002. Edisi Kedua, PT. Prehallindo, Jakarta

Hasibuan, Malayu S.P. Manajemen Sumber Daya Manusia, 2010. Jakarta: PT Bumi Aksara

Hersusdadikawati, Endang. Pengaruh Kepuasan atas Gaji terhadap Keinginan untuk Berpindah Kerja, dengan Komitmen Organisasionalsebagai variabel intervening (Studi Empiris pada Dosen Akuntansi Perguruan Tinggi Swasta Jawa Tengah), 2005. Jurnal Studi Manajemen \& Organisasi Vol.2 No.1 Januari : hal.85-110.

Nurjaman, Kadar. Manajemen Personalia, 2014. Bandung: CV. Pustaka Setia.

Rivai, Veithzal dan Sagala, Ella Jauvani. Manajemen Sumber Daya Manusia untuk Perusahaan dari Teori ke Praktik, 2010. Jakarta: PT Raja Grafindo.

Sihotang. (2007). Manajemen Sumber Daya Manusia, 2007. Jakarta : PT. Pradnya Paramita.

Sugiyono. Metode Penelitian Pendidikan Pendekatan Kuantitatif, Kualitatif, dan R\&D. Bandung: Alfabeta.

Zeffane. Organizational Behavior A Global Perspective, 2003. Australia: John Wiley and Sons Australia Ltd. 